\title{
Terpene-Rich Medicinal Plant Spices for Flavoring of Processed Tropical Food
}

\author{
Appolonia A. Obiloma1, Wenceslaus C. Madu1, Godson 0. Osuji2*, Peter A. Ampim², \\ Aruna D. Weerasooriya2 ${ }^{2}$, Laura E. Carson ${ }^{2}$ \\ ${ }^{1}$ Medicinal Plants Research and Food Processing Unit, Imo State Polytechnic, Owerri, Nigeria \\ ${ }^{2}$ Depatment of Plant Systems, College of Agriculture and Human Sciences, Prairie View A\&M University, \\ Prairie View, TX, USA \\ Email: ^goosuji@pvamu.edu, osujigodson99@gmail.com
}

How to cite this paper: Obiloma, A.A., Madu, W.C., Osuji, G.O., Ampim, P.A., Weerasooriya, A.D. and Carson, L.E. (2019) Terpene-Rich Medicinal Plant Spices for Flavoring of Processed Tropical Food. American Journal of Plant Sciences, 10, 572-577.

https://doi.org/10.4236/ajps.2019.104041

Received: February 21, 2019

Accepted: April 19, 2019

Published: April 22, 2019

Copyright $\odot 2019$ by author(s) and Scientific Research Publishing Inc. This work is licensed under the Creative Commons Attribution International License (CC BY 4.0).

http://creativecommons.org/licenses/by/4.0/

\begin{abstract}
Tropical medicinal plant spices have remained underutilized in commercial food processing because of the inadequate chemical characterization of their terpene compositions. The activity of medicinal plants used in flavoring is due to their terpene contents. Terpene contents of Aframomum danielli seeds, Xylopia aethiopica fruits, Syzygium aromaticum leaves, Piper guineense seeds, and Monodora myristica seeds were determined using headspace solid-phase microextraction combined with gas chromatography-mass spectrometry. $P$. guineense is rich in terpinene and terpinolene $(2.5 \mathrm{~g}$ per 100 g), S. aromaticum has caryophyllene $(0.68 \mathrm{~g}$ per $100 \mathrm{~g}) ; A$. danielli is rich in ocimene ( $1.65 \mathrm{~g}$ per $100 \mathrm{~g})$; $X$. aethiopica is rich in ocimene $(2.94 \mathrm{~g}$ per $100 \mathrm{~g})$; M. mystristica is rich in delta carene $(0.49 \mathrm{~g}$ per $100 \mathrm{~g})$. Combinations of the five medicinal plant spices are being applied as flavorings in packaged tropical food.
\end{abstract}

\section{Keywords}

$\gamma$-Terpinene, $\beta$-Caryophyllene, Ocimene, Delta Carene, African Rain Forest, Microextraction GC-MS

\section{Introduction}

Terpenes comprise the largest class of natural products with more than 30,000 compounds [1]. But tropical medicinal spices have remained underutilized in commercial food processing because of the inadequate chemical characterization of their terpene compositions. Spices are aromatic flavoring added to food to enhance organoleptic properties, making it attractive and palatable [2]. The uses of terpenes as flavor, food additives, vitamins, sweeteners, pharmaceuticals, medicines, and folklore spices in aromatherapy products have benefitted human- 
kind [3]. The wider functions of terpenes in plant biology include light-harvesting pigments in photosynthesis, attraction of insect pollinators, defense against feedants and pathogens, and as mediators in the interactions of plants with other organisms. Although many plant species contain the terpene biochemical pathways [4], the diversity of the chemical structures of terpenes implies that individual groups of related terpenes with the desired biological activities are found only in a few plant families. Furthermore, the concentrations of the terpenes and phytochemicals may be so low in the plant tissue that their potency may be variable and low accordingly [5] due to the dependence of the growth of medicinal plants on environmental conditions (soil type, mineral nutrients, climate, time of harvest). Only a few studies have applied reliable analytical tools to determine the terpene compositions of tropical medicinal plants [6] [7]. The terpene compositions of each medicinal spice are unique taxonomical properties [3] that have been applied since ancient times for characterizing the ethnomedicinal application of each plant species [8]-[12]. Therefore, the aim of this study was to determine the concentrations of terpenes in medicinal plants that are used as spices in traditional cultures in the tropical rain forests of Africa so as to encourage their utilization as flavoring, sweeteners, additives, and supplements in commercial food processing industries.

Some botanical background of African medicinal spices: Aframomum danielli (alligator pepper) is a perennial herbaceous plant indigenous to West Africa. This spice plant of the family Zingiberaceae is also known as "Olima" in Igbo [13]. The seeds are smooth and shining olives. It is traditionally used to preserve food due to its bacteriostatic properties [14]. Xylopia aesthiopica is an evergreen tree of the family Annonaceae, found in the coastal rain forests of tropical Africa. It is known as Uda in Igbo, Eru in Yoruba, and Illa in Ibibio. Dry fruit is used as spice; but the roots, leaves, and bark are used in ethnomedicine for treatment of hemorrhoids, and jaundice, as anthelmintics, and as lactating aid [15] [16]. Syzygium aromaticum is a tree of the Myrtaceae family. The leaves and flowers are spices used for traditional food preservative and for medicinal purposes [17]; but the volatile oil from the buds is used as antiseptic [18]. Piper guineense (Uziza; Ashanti pepper), Piperaceae is a vine in the West African rain forest. The flowers are dioecious. The male flower has 2 - 3 stamens; the female flower has 3 - 5 stigmas. For identification, the fruits are prolate and semi-spherical, and retain their curved stalks like tadpoles. Piper guineense has anti-sickling phytochemicals [19]. Monodora myristica is a deciduous ornamental evergreen tree in the rain forest, the trunk can be up to 2 meters in diameter; the leaves are orchid-like; its flowers are scented. The seeds are embedded in white sweet-smelling pulp of a long fruit. The seeds are aromatic spicy, added as stimulant to herbal medicines [16].

\section{Materials and Methods}

\subsection{Plant Materials}

Aframomum danielli (Alligator paper) dry seeds, Xylopia aethiopica (Udah: Ig- 
bo) dry fruits, Syzygium aromaticum (Clove) fresh leaves and flowers, Piper guineense (Uziza: Igbo) dry seeds, and Monodora mystritica (Ehu: Igbo; Abo lakoshe: Yoruba) dry seeds were sourced from indigenous Igbo, Yoruba, and Ashanti markets in West African rain forests, and identified by plant taxonomists from Imo State Polytechnic, Owerri; Imo State University, Owerri; and by ethnobotanists at Green Healthcare Foundation Botanical Gardens in Owerri West, Nigeria. Seeds were cleaned, briskly washed with distilled water, air dried and ground to powder with motar and pistle. Flowers and leaves were air-dried between filter papers, followed by grinding to powder with motar and pistle. Powders of plant materials were stored in the fridge before chemical analyses.

\subsection{Chemical Analysis}

Terpene content was determined by Anresco Laboratories, San Francisco using their proprietary Headspace GC-MS method for comprehensive terpene profiling in Cannabis in which plant material is homogenized with dry ice, and $20 \mathrm{mg}$ is loaded into the head space vial cap and incubated; followed by injection into Shimadzu QP 2010 SE GC-MS. The software used for acquiring/processing the spectra was Shimadzu GC-MS solution Version 4.42. Quality control for the terpene concentrations was assured by performing four points standard curve of all 27 terpenes including the method blank.

\section{Results and Discussion}

Possible terpene-rich medicinal plants and spices (Table 1) that are culturally utilized in food preparation were selected based on orally-communicated African ethno-botanic traditional history, and from the literature [16]. The tissues of the plants that are normally used in food preparations were analyzed. The results (Table 1) showed that each plant species has a characteristic set level of a mix of terpenes that determine the aroma and taste imprint of the plant. Piper guineese (Igbo: Uziza) seed is characterized by its high accumulation of $\gamma^{\text {-terpinene }}$ (1.23 $\mathrm{g}$ per $100 \mathrm{~g})$ and terpinolene ( $1.1 \mathrm{~g}$ per $100 \mathrm{~g})$ which are known for their turpentine, citrus-like orange and lemon flavors [20]. Syzygium aromaticum (Igbo: Osaragbogo-eze) leaves and flowers have the highest accumulation of caryophyllene $(0.68 \mathrm{~g}$ per $100 \mathrm{~g})$ and ocimene $2(0.14 \mathrm{~g}$ per $100 \mathrm{~g})$ known for their peppery, spicy, and woody taste. Ocimene 2 ( $1.65 \mathrm{~g}$ per $100 \mathrm{~g})$ is also the colorless liquid with a pleasant odor and the dominant terpene in the seeds of Aframomum danielli (alligator pepper), and Xylopia aethiopica (2.9 g per $100 \mathrm{~g}$ ) used as dietary supplements and spices in the rain forests of Africa [16] [21]. The abundant terpene in Monodora mystristica (Igbo: Ehu) seed is delta 3-carene (0.49 g per $100 \mathrm{~g})$ known for its penetrating sweet, earthy, lemon flavor used as a condiment for soup flavoring in West Africa [16]. The medicinal plant spices are being deployed in the flavoring of processed tropical food thereby increasing the farm income of the indigenous (limited resources) farmers who cultivate the crops. In addition to the rich terpene composition of the five aromatic medicinal 
Table 1. Terpene profiles of tropical African medicinal plants and spices (More details are available under supplementary materials).

\begin{tabular}{|c|c|c|c|c|c|}
\hline Terpenes & $\begin{array}{c}P . \\
\text { guineense }\end{array}$ & $\begin{array}{c}S . \\
\text { aromaticum }\end{array}$ & $\begin{array}{c}A . \\
\text { danielli }\end{array}$ & $\begin{array}{c}X . \\
\text { aethiopica }\end{array}$ & $\begin{array}{c}M . \\
\text { mystristica }\end{array}$ \\
\hline & \multicolumn{5}{|c|}{$(\mathrm{mg}$ per $100 \mathrm{~g})$} \\
\hline 1) $\alpha$-Pinene & 117 & $-0-$ & 32 & 81 & 215 \\
\hline 2) $\beta$-Pinene & 129 & 19 & 131 & 112 & 11 \\
\hline 3) Camphene & 25 & $-0-$ & $-0-$ & 15 & $-0-$ \\
\hline 4) $\beta$-Myrcene & 67 & $-0-$ & 131 & 55 & 147 \\
\hline 5) $\Delta$ 3-Carene & 260 & $-0-$ & $-0-$ & 20 & 493 \\
\hline 6) Limonene & 144 & 12 & 41 & 82 & 100 \\
\hline 7) $\alpha$-Terpinene & 104 & $-0-$ & $-0-$ & 9 & 2 \\
\hline 8) Ocimene 1 & 41 & $-0-$ & $-0-$ & 10 & 31 \\
\hline 9) Ocimene 2 & 51 & 142 & 1655 & 2936 & 43 \\
\hline 10) p-Cymene & 21 & $-0-$ & $-0-$ & $-0-$ & 288 \\
\hline 11) Eucalyptol & 14 & 36 & 248 & 104 & $-0-$ \\
\hline 12) $\gamma$-Terpinene & 1229 & 53 & 53 & 307 & 2 \\
\hline 13) Terpinolene & 1105 & 38 & 11 & 51 & $-0-$ \\
\hline 14) Linalool & 53 & $-0-$ & $-0-$ & 68 & 62 \\
\hline 15) Isopulegol & $-0-$ & $-0-$ & 5 & $-0-$ & 2 \\
\hline 16) Menthol & $-0-$ & $-0-$ & $-0-$ & 36 & $-0-$ \\
\hline 17) (-)-Borneol & $-0-$ & $-0-$ & $-0-$ & 6 & $-0-$ \\
\hline 18) Terpineol & 15 & $-0-$ & 126 & 32 & 10 \\
\hline 19) Citronellol & $-0-$ & $-0-$ & $-0-$ & $-0-$ & 37 \\
\hline 20) Caryophyllene oxide & $-0-$ & 16 & $-0-$ & $-0-$ & $-0-$ \\
\hline 21) $\beta$-Caryophyllene & 411 & 682 & 28 & 23 & 5 \\
\hline 22) $\alpha$-Humelene & 130 & 125 & $-0-$ & 6 & 3 \\
\hline 23) Nerolidol 1 & 18 & 6 & $-0-$ & $-0-$ & 6 \\
\hline 24) Nerolidol 2 & 22 & $-0-$ & $-0-$ & $-0-$ & $-0-$ \\
\hline 25) Guaiol & 23 & $-0-$ & $-0-$ & $-0-$ & $-0-$ \\
\hline
\end{tabular}

plants studied, each plant species has its suite of pharmacologically important compounds that have been documented in great detail [16], a discussion of which is outside the scope of this research project.

The conventional approach for terpene analysis involves a solvent extraction followed by gas chromatography-flame ionization detection (GC-FID) analysis. The Anresco instrument suite involved headspace solid phase microextraction (HS-SPME) combined with GC-MS for the quantitation of terpenes. HS-SPME brings several advancements over solvent extraction method because it avoids destruction of the plant sample, requires micro-quantities of plant sample, and avoids interference from co-extracted materials which are extremely variable in solubility in solvent. The micro-quantity sample amount effectively forms a single-phase gas system in the headspace vial at equilibrium, thereby making the 
terpene quantitation spectra extraordinarily accurate [22].

\section{Acknowledgements}

The research project was supported through the Evans Allen Fund made available to Prairie View A\&M University by USDA-NIFA. Imo State Polytechnic is in MOU affiliation to Prairie View A\&M University. Thanks to Drs. Wright, Akujuobi, Palmer, D. Myers, E. Myers, Fares, A. Parks, and C. Gee for formulating the MOU.

\section{Conflicts of Interest}

The authors declare no financial conflict of interests in the MOU research projects.

\section{References}

[1] Dagenhardt, J., Kollner, T.G. and Gershenzon, J. (2009) Monoterpene and Sesquiterpene Synthases and the Origin of Terpene Skeletal Diversity in Plants. Phytochemistry, 70, 1621-1637. https://doi.org/10.1016/j.phytochem.2009.07.030

[2] Nice, J. (1995) The Complete Book of Homemade Preserves.

[3] Bohlmann, J. and Keeling, C.I. (2008) Terpenoid Biomaterials. Plant Journal, 54, 656-669. https://doi.org/10.1111/j.1365-313X.2008.03449.x

[4] Sallaud, C., Rontein, D., Onillon, S., Jabes, F., Duffe, P., Giacalone, C., Thoraval, S., Escoffier, C., Herbette, G., Leonhardt, N. and Causses, M. (2009) A Novel Pathway for Sesquiterpene Biosynthesis from Z,Z-Farnesyl Pyrophosphate in the Wild Tomato Solanum habrochaites. The Plant Cell, 21, 301-317. https://doi.org/10.1105/tpc.107.057885

[5] Osuji, G.O., Gao, M., Carson, L., Ampim, P., Weerasooriya, A., Johnson, P., Duffus, E., Woldesenbet, S., Kirven, J., Williams, E.L., Johnson, D. and Clarke, C. (2007) Biotechnological Induction of Shikimate-Based Antioxidant Accumulation in Phyla dulcis. The Natural Products Journal, 7, 104-111. https://doi.org/10.2174/2210315506666161017124440

[6] Koudou, J., Osibi, A.W.E., Aklikokou, K., Abena, A.A., Gbeassor, M. and Bessiere, J.M. (2007) Chemical Composition and Hypotensive Effects of Essential Oil of $\mathrm{Mo}$ nodora myristica Gaertn. Journal of Biological Sciences, 7, 937-942. https://doi.org/10.3923/jbs.2007.937.942

[7] Thang, T.D., Dai, D.N., Hoi, T.M. and Ogunwande, I.A. (2013) Chemical Composition of the Leaf Essential Oils of Some Annonaceae from Vietnam. The Journal of Essential Oil Research, 25, 85-91. https://doi.org/10.1080/10412905.2012.755475

[8] Onyenibe, N.S., Fowokemi, K.T. and Emmanuel, O.B. (2015) African Nutmeg (Monodora myristica) Lowers Cholesterol and Modulates Lipid Peroxidation in Experimentally Induced Hypercholesteromic Male Wister Rats. International Journal of Biomedical Science, 11, 86-92.

[9] Leghissa, A., Hildenbrand, Z.L. and Schug, K.A. (2018) A Review of Methods for the Chemical Characterization of Cannabis Natural Products. Journal of Separation Science, 41, 398-415. https://doi.org/10.1002/jssc.201701003

[10] Aroyeun, S.O., Adegoke, G.O., Varga, J., Karolyi, P., Kuscbe, S. and Valgvolgyi, C. (2011) Potential of Aframomum danielli Spice Powder in Reducing Ochratoxin A in 
Cocoa Powder. American Journal of Food and Nutrition, 1, 155-165. https://doi.org/10.5251/ajfn.2011.1.4.155.165

[11] Paumgartten, F.J.R., De-Carvalho, R.R., Souza, C.A.M., Madi, K. and Chahoud, I. (1998) Study of the Effects of $\beta$-myrcene on Rat Fertility and General Reproductive Performance. Brazilian Journal of Medical and Biological Research, 31, 955-965. https://doi.org/10.1590/S0100-879X1998000700012

[12] Akpuaka, M.U., Ezem, S.N., Ogbuagu, A.S. and Ekpunobi, U.E. (2015) The Chemical Constituents of Some Medicinal Plants Used in Health Management in South East Nigeria: A Review. International Journal of Chemical and Biomedical Sciences, 1, 17-24.

[13] Adegoke, O.A., Makinde, O., Falade, K.O. and Peters, P.I. (2003) Extraction and Characterization of Anti-Oxidants from Afromomum melagueta and Xylopia aesthiopica. European Food Research and Technology, 216, 526-528. https://doi.org/10.1007/s00217-003-0683-6

[14] Fasoyiro, S.B. and Adegoke, G.O. (2007) Phytochemical Characterization and the Antimicrobial Property of Aframomum danielli Extract. African Journal of Agricultural Research, 2, 76-79.

[15] Oladunmoye, M.K. and Kehinde, F.Y. (2011) Ethnobotanical Survey of Medicinal Plants Used in Treating Viral Infections among Yoruba Tribe of South Western Nigeria. African Journal of Microbiology Research, 5, 2991-3004. https://doi.org/10.5897/AJMR10.004

[16] Iwu, M.M. (2014) Handbook of African Medicinal Plants. 2nd Edition, CRC Press, Boca Raton, New York. https://doi.org/10.1201/b16292

[17] Cortés-Rojas, D.F., de Souza, C.R.F. and Oliveira, W.P. (2014) Clove (Syzygium aromaticum): A Precious Spice. Asian Pacific Journal of Tropical Biomedicine, 4, 90-96. https://doi.org/10.1016/S2221-1691(14)60215-X

[18] Bhowmik, D., Kumar, K.P.S., Yadav, A., Srivastava, S., Paswan, S. and Dutta, A.S. (2012) Indian Traditional Herbs Syzygium aromaticum and Its Health Benefits. Journal of Pharmacognosy and Phytochemistry, 1, 13-22.

[19] Ameh, S.J., Obodozie, O.O., Inyang, U.S., Abubakar, M.S. and Garba, M. (2011) Climbing Black Pepper (Piper guineense) Seeds as an Antisickling Remedy. In: Nuts and Seeds in Health and Disease Prevention, Chapter 40, Elsevier Inc., London, New York. https://doi.org/10.1016/B978-0-12-375688-6.10040-4

[20] Eggersdorfer, M. (2000) Terpenes. Ullmann's Encyclopedia of Industrial Chemistry. https://doi.org/10.1002/14356007.a26_205

[21] Asekun, O.T. and Adeniyi, B.A. (2004) Antimicrobial and Cytotoxic Activities of the Fruit Essential Oil of Xylopia aethiopica from Nigeria. Fitoterapia, 75, 368-370. https://doi.org/10.1016/j.fitote.2003.12.020

[22] Halpenny, M. and Stenerson, K.K. (2017) Quantitative Determination of Terpenes in Cannabis Using Headspace Solid Phase Microextraction and GC-MS. Gersten Application Note No. 189. 